\title{
Changes in the non-crustacean zooplankton community in the middle Adriatic Sea during the Eastern Mediterranean Transient
}

\author{
MIRNA BATISTIĆ \\ RADE GARIC \\ MIRA MOROVIĆ \\ ${ }^{1}$ University of Dubrovnik, Institute for Marine \\ and Coastal Research, Kneza D. Jude 12, \\ 20000 Dubrovnik, Croatia \\ ${ }^{2}$ Institute of Oceanography and Fisheries, \\ I. Meštrovića 63, 21000 Split, Croatia

\section{Correspondence:} \\ Mirna Batistić \\ e-mail:mirna.batistic@unidu.hr
}

Key words: zooplankton, hydroclimatic changes, Middle Adriatic

Received May 26, 2015

Revised February 18, 2016.

Accepted February 18, 2016.

\begin{abstract}
Background and Purpose: Here we presented changes in the non-crustacean zooplankton community in the years characterized by the large scale changes in the thermohaline circulation in the East Mediterranean known as the Eastern Mediterranean transient (EMT) and stronger inflow of colder and less saline Modified Atlantic Water (MAW) into the Adriatic Sea.
\end{abstract}

Material and Method: Monthly samplings from February 1995 to February 1996, were performed at fixed station Stončica near the Island of Vis in the open oligotrophic Middle Adriatic waters. Zooplankton samples, taken vertically from $100 \mathrm{~m}$ to the surface using a Nansen net with $125-\mu \mathrm{m}$ mesh size were analyzed in detail for the following zooplankton taxa: Hydromedusae, Calycophorae, Ctenophora, Pteropoda, Heteropoda, Polychaeta and Chaetognatha.

Results and Conclusions: Among the investigated non-crustacean zooplankton three species were registered for the first time, while one species reappeared after years of absence. Compared with earlier data there was a dramatic change in dominant species of calycophoran medusae, pteropods and polychaetes. Data presented herein provide baseline information that is essential for the evaluation of impact of hydroclimatic changes on the zooplankton community, which started in the East Mediterranean in the 1990s and are still on going.

\section{INTRODUCTION}

$A$ driatic Sea is divided into three parts: the North, the Middle and the A South Adriatic. The North Adriatic is very shallow, with an average depth of 30 to $40 \mathrm{~m}$ and maximum of $70 \mathrm{~m}$, while the Middle Adriatic is much deeper, reaching $280 \mathrm{~m}$ in the Jabuka Pit. It is separated from the deepest South Adriatic by the $170 \mathrm{~m}$ deep Palagruža Sill. Adriatic Sea is connected with the Mediterranean Sea trough the Otranto Strait. The deepest part of the South Adriatic (cca. $1240 \mathrm{~m}$ depth) is influenced by Ionian and eastern Levantine waters, and plays an important role as a site of the formation of dense water, the Adriatic Dense Water (AdDW) (1). The AdDW spreads into the Ionian abyss and represents the main component of the East Mediterranean Deep Water (EMDW).

Furthermore, it has been demonstrated that the Ionian upper layer circulation, the thermohaline properties of the $\operatorname{AdDW}-\mathrm{EMDW}(2,3)$ and the salt distribution over the East Mediterranean (4) are interconnected through the BiOS, a feedback mechanism between the South 
Adriatic (SA) and Ionian Sea (IS) that changes the upperlayer circulation of the North Ionian Gyre (NIG). During the last 25 years it has been observed that the upper-layer circulation in the Ionian reversed on decadal time scales, from anticyclonic to cyclonic and vice-versa $(3,4,5)$. While the cyclonic regime brings warmer and saltier waters of Levantine origin into the Adriatic, the anti-cyclonic pattern favours the inflow of colder and less saline Ionian waters diluted by the Atlantic Water (5). During the early 1990s, the deep water formation areas switched from the SA to the Cretan Sea (6). This event, known as the East Mediterranean Transient (EMT), caused an abrupt change in the East Mediterranean circulation and uniquely strengthened inflow of Modified Atlantic Water (MAW) into the Adriatic (2,7). This interesting phenomenon caused large changes in the Mediterranean marine environment (e.g. 4, 5, 8,9) that are not yet fully known.

BiOS mechanism has important influence on biological and chemical properties of the South Adriatic (3, 5, 11), as well as on physical and chemical properties of the Middle Adriatic $(9,10)$. The influence of $\mathrm{BiOS}$ on plankton communities and the advection of immigrant zooplankton species has only been known for the South Adriatic non-crustacean zooplankton community (11). Magnitude of influence on the zooplankton community in the rest of the Adriatic is unknown to date. We par- tially addressed this question by analyzing plankton records collected in the Middle Adriatic in 1995/1996, the years characterized by the abrupt change in the eastern Mediterranean circulation (EMT) and advection of Modified Atlantic Water (MAW) in the Adriatic. Zooplankton data originate from the permanent observation site Stončica in the Middle Adriatic which is strongly influenced by incoming water masses from the Ionian Sea. The importance of the open Middle Adriatic in tracing the Adriatic circulation and water masses has been recognized from the beginning of modern oceanographic investigations of the Adriatic (12, 13, 14). Long-term zooplankton data from Stončica have been analysed in several papers $(15,16,17,18,19)$. However, considering that zooplankton investigations in this area were largely focused on crustacean zooplankton (see in ref. 16), this paper brings valuable additional perspective on changes in biological properties of the water column based on the non-crustacean zooplankton community in the context of large scale influences on thermohaline circulation within this area.

\section{MATERIAL AND METHODS}

Monthly samplings from February 1995 to February 1996, were performed at fixed station Stončica near the Island of Vis in the open Middle Adriatic (4302'38'N $16^{\circ} 17^{\prime} 7^{\prime \prime} \mathrm{E}$, depth $106 \mathrm{~m}$, Fig. 1) in the frame of regular

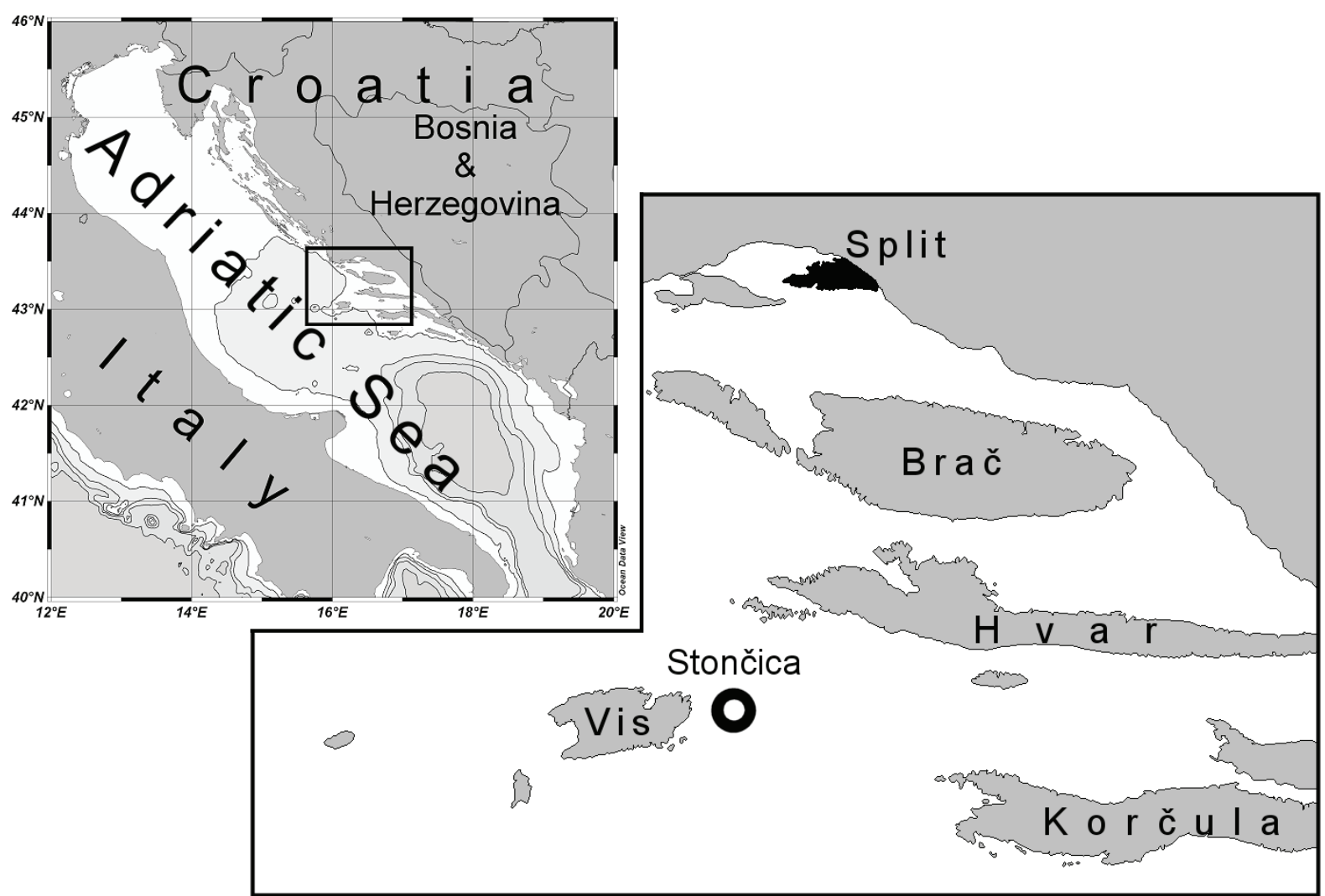



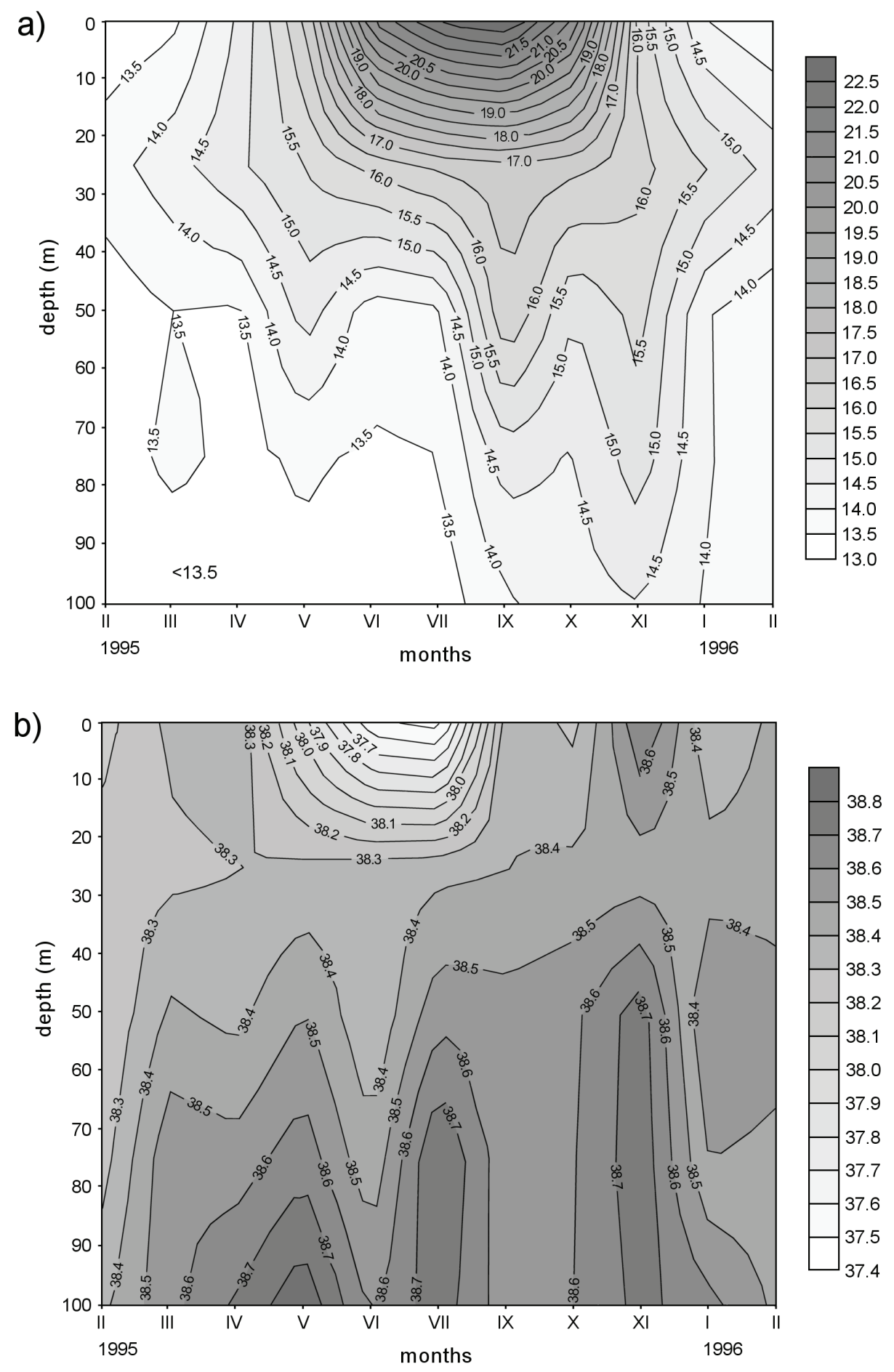

Figure 2. Temperature and salinity at Stončica station during the investigated period.

monitoring carried out by the Institute of oceanography and fisheries in Split (www.izor.hr). Based on long-term monitoring of the chemical and biological parameters, Stončica site is designated as an oligotrophic open sea site, characterized by high transparency and decreased phytoplankton and zooplankton abundance, in comparison to more productive coastal areas in the Middle Adriatic.
Zooplankton samples, taken vertically from $100 \mathrm{~m}$ to the surface using a Nansen net with $125-\mu \mathrm{m}$ mesh size $(57$ $\mathrm{cm}$ mouth diameter and $255 \mathrm{~cm}$ total length), were preserved in $2.5 \%$ formaldehyde and analyzed in detail for the following zooplankton taxa: Hydromedusae, Siphonophorae, Ctenophora, Pteropoda, Heteropoda, Polychaeta and Chaetognatha. Taxonomic identification and 
counting of individuals were performed with a Zeiss stereomicroscope at 25x and 40x magnifications. Abundance of all groups except calycophoran siphonophores is presented as the number of specimens per $10 \mathrm{~m}^{3}$. Calycophoran abundance was expressed according to the number of nectophores (polygastric stage) of each species (nectophores per $10 \mathrm{~m}^{3}$ ).

Water samples for oceanographic measurements were taken with 5-litre Niskin bottles at standard depths of 0 , 5, 10, 20, 30, 50, 75 and $100 \mathrm{~m}$. Seawater temperature and salinity was measured using automatic CTD probe.

The relationship between groups, dominant species and environmental parameters was tested using the Pearson's rank correlation coefficient. Dataset was log transformed to ensure that the variables normally distributed.

The dominant species within a particular group were determined according to their contribution in total abundance (percentage number, PN) and their occurrence in total number of samples (frequency of occurrence, $\mathrm{F}$ ) where $\mathrm{PN}$ is $\geq 10 \%$ and $\mathrm{F}$ is $\geq 50 \%(20,21,22,23,24)$. Percentage number was calculated as follows:

$\mathrm{PN}=(\mathrm{pi} / \mathrm{P}) \times 100$ where pi is number of individuals of particular species and $\mathrm{P}$ is total number of individuals of all species.

Frequency of occurrence was calculated using the following formula:

$\mathrm{F}=(\mathrm{ni} / \mathrm{N}) \times 100$ where $\mathrm{ni}$ is number of samples where the species was recorded and $\mathrm{N}$ is total number of samples.

\section{RESULTS}

\section{Hydrographic parameters}

The temperature varied between $13.4^{\circ} \mathrm{C}$ in January and $23.0^{\circ} \mathrm{C}$ in July (Fig. 2). Periods of isothermy occurred in January, February, March and November. Between June and September there was a marked thermal stratification,
Table 1. Pearson coefficient of correlation between abundance of zooplankton groups and hydrographic parameters $(n=11)$. Asterisks indicate the level of significance: ${ }^{*} p<0.05 ;{ }^{* *} p<0.01$; ${ }^{* *} p<0.001$.

\begin{tabular}{|lcc|}
\hline Taxa & Temperature & Salinity \\
\hline Groups & & \\
\hline Hydromedusae & -0.182 & -0.288 \\
Calycophorae & -0.199 & -0.322 \\
Heteropoda & $0.572^{*}$ & -0.198 \\
Pteropoda & 0.313 & $-0.706^{* *}$ \\
Polychaeta & 0.128 & -0.446 \\
Chaetognatha & $0.842^{* * *}$ & -0.134 \\
\hline
\end{tabular}

with thermocline positioned between 10 and $20 \mathrm{~m}$ depth (June and July), and 30 and $50 \mathrm{~m}$ depth (September).

The vertical salinity distribution indicated that major fluctuations occurred in the upper $10 \mathrm{~m}$, with lowest values in July (37.46 at $0 \mathrm{~m}$, Fig. 2). Minimal fluctuations were recorded in winter months and during the autumn isothermal period. Halocline was formed in May and June between 10 and $20 \mathrm{~m}$ and in July between 5 and 10 m. Below 20 m, salinity was higher than 38.20 (Fig. 2).

\section{Population structure and abundance of non-crustacean zooplankton}

The most abundant groups were Chaetognatha, Pteropoda, Hydromedusae and Calycophorae (Fig. 3). Annual variations of abundances are presented in Fig. 3. Total abundances of chaetognaths and heteropods were in significant correlation with temperature $(\mathrm{p}<0.001$ and $\mathrm{p}<0.05$, respectively) while the total abundance of pteropods was in correlation with salinity $(\mathrm{p}<0.01)$ (Table 1$)$.

During the investigated period 50 species were identified (Table 2): 11 species of Hydromedusae, 8 species of Calycophorae, 12 species of Pteropoda, 3 species of Het-

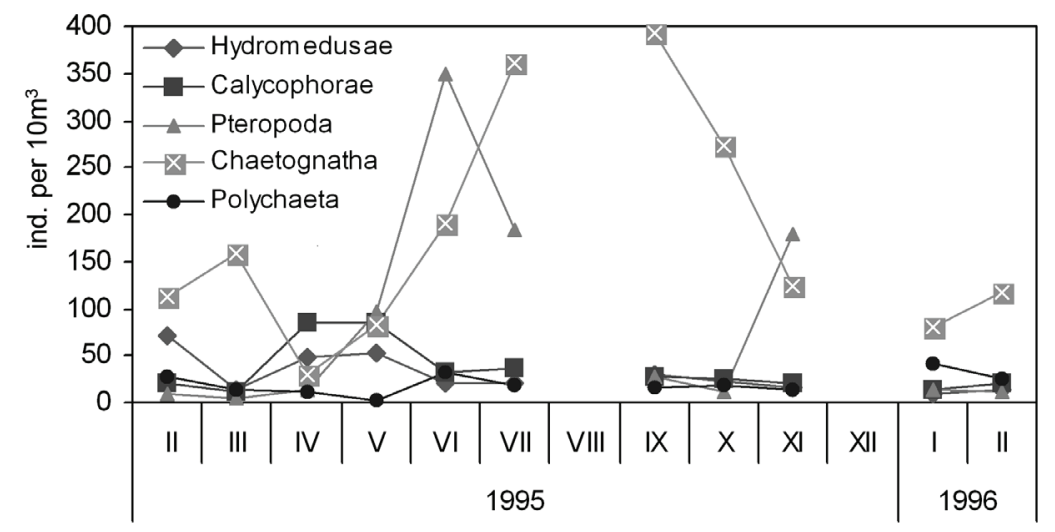

Figure 3. Abundances of investigated zooplankton groups. 
Table 2. Mean (ind. per $10 \mathrm{~m}^{3}$ ), standard deviation (SD), percentage number (PN, \%) and frequency of occurrence ( $F, \%)$ of the different taxa in the respective group.

\begin{tabular}{|c|c|c|c|c|}
\hline Taxa & Mean & SD & PN & $\mathrm{F}$ \\
\hline \multicolumn{5}{|l|}{ Hydromedusae } \\
\hline Sarsia gemmifera & 0.07 & 0.24 & 0.3 & 9 \\
\hline Euphysa aurata & 0.36 & 0.89 & 1.2 & 18 \\
\hline Laodicea undulata & 0.11 & 0.20 & 0.4 & 18 \\
\hline Obelia spp. & 0.65 & 1.24 & 2.3 & 27 \\
\hline Clytia hemisphaerica & 3.45 & 5.62 & 8.7 & 70 \\
\hline Liriope tetraphylla & 5.56 & 5.23 & 22.8 & 100 \\
\hline Aglaura hemistoma & 13.35 & 16.71 & 46.3 & 100 \\
\hline Persa incolorata & 0.91 & 1.23 & 3.1 & 64 \\
\hline Rhopalonema velatum & 1.52 & 1.08 & 6.3 & 70 \\
\hline Solmundella bitentaculata & 1.09 & 1.42 & 3.8 & 73 \\
\hline Solmaris leucostyla & 0.25 & 0.41 & 0.9 & 30 \\
\hline \multicolumn{5}{|l|}{ Calycophorae } \\
\hline Lensia subtilis & 5.85 & 4.31 & 16.8 & 100 \\
\hline Muggiaea atlantica & 19.24 & 27.46 & 55.3 & 100 \\
\hline M. kochii & 4.64 & 5.58 & 12.1 & 100 \\
\hline Chelophyes appendiculata & 0.11 & 0.26 & 0.3 & 18 \\
\hline Eudoxoides spiralis & 0.44 & 0.52 & 1.3 & 55 \\
\hline Sphaeronectes gracilis & 4.22 & 4.42 & 12.1 & 100 \\
\hline Abylopsis tetragona & 0.07 & 0.24 & 0.2 & 9 \\
\hline Bassia bassensis & 0.62 & 1.99 & 1.8 & 18 \\
\hline \multicolumn{5}{|l|}{ Ctenophora } \\
\hline Ctenophora unindentified & 0.87 & 1.93 & & 30 \\
\hline \multicolumn{5}{|l|}{ Heteropoda } \\
\hline Atlanta peronii & 0.47 & 1.44 & 62.0 & 18 \\
\hline Protatlanta souleyeti & 0.25 & 0.60 & 33.3 & 27 \\
\hline Firoloida desmarestia & 0.04 & 0.12 & 4.8 & 9 \\
\hline \multicolumn{5}{|l|}{ Pteropoda } \\
\hline Limacina inflata & 23.02 & 44.23 & 26.2 & 100 \\
\hline L. trochiformis & 3.84 & 0.6 .9 & 4.2 & 70 \\
\hline Styliola subula & 0.04 & 0.12 & 0.1 & 9 \\
\hline Creseis virgula & 35.85 & 58.91 & 43.7 & 81 \\
\hline C. acicula & 14.76 & 38.79 & 18.0 & 54 \\
\hline Hyalocylix striata & 0.15 & 0.37 & 0.2 & 18 \\
\hline Clio pyramidata & 0.04 & 0.12 & 0.1 & 9 \\
\hline Clio cuspidata & 0.04 & 0.12 & 0.1 & 9 \\
\hline Cavolinia inflexa & 1.16 & 3.21 & 0.3 & 36 \\
\hline Peracle reticulata & 0.47 & 1.44 & 0.6 & 18 \\
\hline Cymbulia peronii & 0.47 & 1.22 & 0.2 & 18 \\
\hline Desmopterus papilio & 0.04 & 0.12 & 0.1 & 9 \\
\hline \multicolumn{5}{|l|}{ Polychaeta } \\
\hline Tomopteris helgolandica & 0.15 & 0.20 & 2.5 & 36 \\
\hline T. elegans & 0.76 & 0.75 & 13.1 & 100 \\
\hline Vanadis crystallina & 0.04 & 0.12 & 0.6 & 9 \\
\hline Callizonella lepidota & 0.11 & 0.19 & 1.9 & 27 \\
\hline
\end{tabular}

\begin{tabular}{|lcccc|} 
Pelagobia longicirrata & 3.64 & 3.93 & 63.1 & 72 \\
Sagitella kowalevskii & 1.05 & 1.46 & 1.9 & 18 \\
Travisiopsis lanceolata & 0.29 & 0.74 & 16.3 & 45 \\
Typhloscolex muelleri & 0.04 & 0.12 & 0.6 & 9 \\
Chaetognatha & & & & \\
Sagitta enflata & 45.09 & 68.78 & 24.7 & 100 \\
S. minima & 122.11 & 88.72 & 67.1 & 100 \\
S. setosa & 1.75 & 1.61 & 1.0 & 81 \\
S. serratodentata & 4.15 & 6.36 & 2.3 & 100 \\
S. bipunctata & 0.11 & 0.19 & 3.7 & 27 \\
S. decipiens & 0.41 & 0.80 & 0.2 & 27 \\
S. lyra & 1.56 & 2.99 & 0.9 & 45 \\
Krohnitta subtilis & 0.04 & 0.12 & 0.1 & 9 \\
\hline
\end{tabular}

Table 3. Pearson coefficient of correlation between abundance of dominant species and hydrographic parameters $(n=11)$. Asterisks indicate the level of significance: ${ }^{*} p<0.05$; ${ }^{* *} p<0.01$; ${ }^{* * *} p<$ 0.001 .

\begin{tabular}{|lcc|}
\hline Taxa & Temperature & Salinity \\
\hline Species & & \\
\hline Aglaura hemistoma & -0.348 & -0.243 \\
Liriope tetraphylla & 0.444 & 0.399 \\
Lensia subtilis & $-0.832^{* * *}$ & 0.098 \\
Muggiaea kochii & 0.330 & $-0.551^{*}$ \\
Muggiaea atlantica & -0.042 & -0.152 \\
Atlanta peronii & 0.249 & -0.288 \\
Protatlanta souleyeti & $0.731^{* *}$ & 0.287 \\
Limacina inflata & 0.076 & $0.599^{*}$ \\
Creseis virgule & 0.297 & $-0.689^{* *}$ \\
Creseis acicula & 0.247 & $-0.656^{* *}$ \\
Pelagobia longicirrata & $-0.569^{*}$ & -0.112 \\
Tomopteris elegans & 0.455 & -0.192 \\
Sagitta enflata & $0.809^{* * *}$ & 0.276 \\
Sagitta minima & $0.559^{*}$ & -0.393 \\
\hline
\end{tabular}

eropoda, 8 species of Polychaeta and 8 species of Chaetognatha. Ctenophores were counted at group level and were found only sporadically. Among these species, four were recorded in the Middle Adriatic for the first time: Muggiaea atlantica (calycophoran), Desmopterus papilio (pteropod), Protatlanta souleyeti (heteropod), Pelagobia longicirrata (pelagic polychaete).

The dominant species of hydromedusae $A$. hemistoma and L. tetraphylla (Table 2) showed generally higher abundances in winter, spring, and autumn (Fig. 4). No correlation was found between abundances of these species 
and hydrographical parameters (Table 3). Among calycophores, L. subtilis, M. kochii and M. atlantica were the most abundant and frequent species (Table 2). L. subtilis
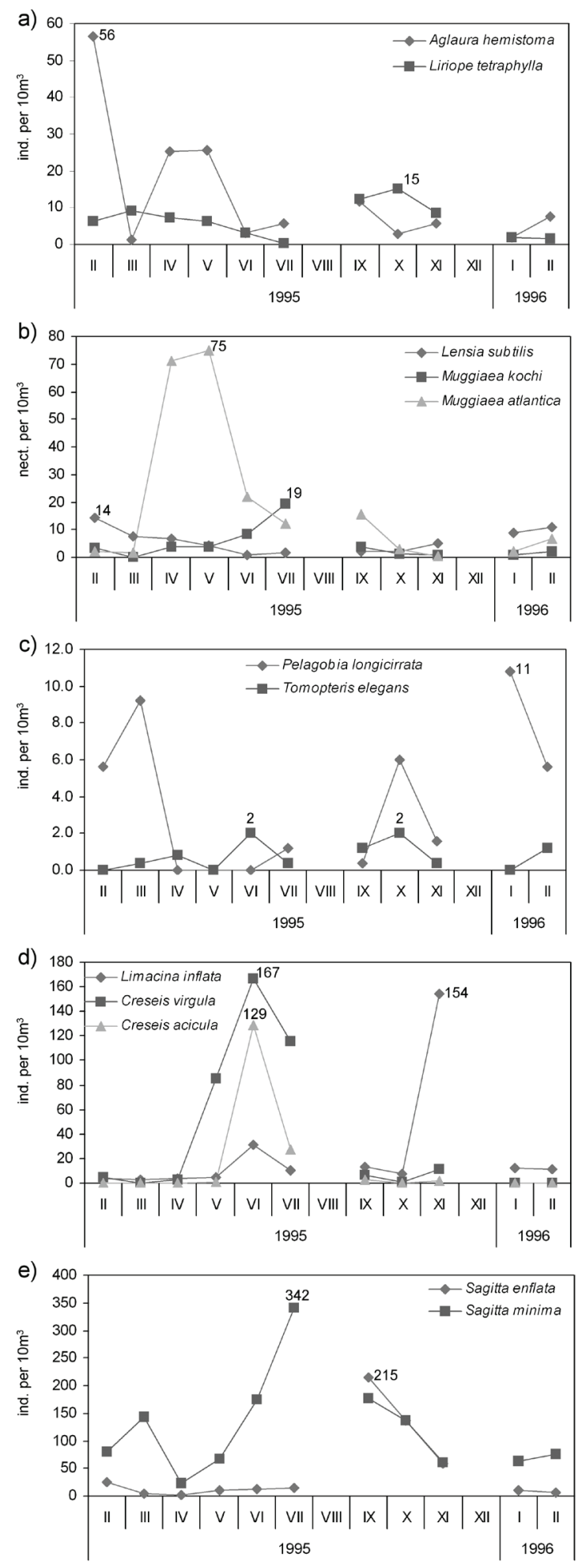

Figure 4. Abundances of dominant species in their respective groups: a) Hydromedusae, b) Calycophorae, c) Polychaeta, d) Pteropoda, e) Chaetognatha. attained higher abundance in winter (Fig. 4) and was in significant negative correlation with temperature ( $<<0.001$, Table 3). M. atlantica was most abundant in spring and attained high abundance in the Middle Adriatic (Fig. 4) very soon after its first record in the South Adriatic in February 1995 (25). Maximal abundance of M. kochii was registered in summer (Fig. 4). Abundance of $M$. kochii was in significant negative correlation with salinity $(\mathrm{p}<0.05$, Table 3$)$. In comparison with studies before 1995, relative abundance of $M$. atlantica in calycophoran community markedly increased, while for $M$. kochii a decrease was registered (Table 4). The most abundant and frequent pteropods were Limacina inflata, Creseis virgula and $C$. acicula (Table 2). L. inflata was most abundant in autumn while $C$. virgula and $C$. acicula peaked in spring-summer period (Fig. 4). The abundances of all three species were in significant correlation with salinity ( $<<0.05 ; \mathrm{p}<0.01 ; \mathrm{p}<0.01$, respectively) (Table 3 ). Abundance and contribution of $C$. acicula in pteropod community was much lower than in previous investigations (Table 4). On the contrary, previously rare $L$. inflata and C. virgula showed relative abundance of 26 and $44 \%$ in the pteropod community, respectively (Table 4). Pteropod Desmopterus papilio was registered for the first time in the Middle Adriatic, in September 1995, with low relative abundance of $0.1 \%$ (Table 4 ).

$P$. longicirrata and T. elegans were the dominant pelagic polychaetes (Table 2). P. longicirrata was most abundant in winter, while T. elegans attained high abundance in warmer part of the year (Fig. 4). Abundances of $P$. longicirrata were in negative significant correlation

Table 4. Relative abundance (\%) of newly recorded and dominant species of calycophorans, pteropods, heteropods and polychaetes in the Middle Adriatic in total number of specimens in the respective group (CA: calycophorae; PT: pteropoda; HT: heteropoda; PH: polychaeta). Comparison of our data and earlier records (references are indicated in parenthesis).

\begin{tabular}{|lcc|}
\hline Species & $\begin{array}{c}\text { Relative } \\
\text { abundance (\%) } \\
\text { in studies earlier } \\
\text { than 1995 }\end{array}$ & $\begin{array}{c}\text { Relative } \\
\text { abundance (\%) } \\
\text { in this study } \\
\text { (annual mean) }\end{array}$ \\
\hline *Muggiaea atlantica (CA) & $/$ & $55 \%$ \\
Muggiaea kochii (CA) & $>30 \%(25,36)$ & $12 \%$ \\
Creseis acicula (PT) & $>80 \%(36,37)$ & $18 \%$ \\
Limacina inflata (PT) & $<5 \%(36)$ & $26 \%$ \\
Creseis virgula (PT) & $<5 \%(36)$ & $44 \%$ \\
*Desmopterus papilio (PT) & $/$ & $<0.1 \%$ \\
Atlanta peronii (HT) & $>50 \%(36)$ & $62 \%$ \\
*Protatatlanta souleyeti (HT) & $/$ & $33 \%$ \\
*Pelagobia longicirrata (PH) & $+(27)$ & $63 \%$ \\
Tomopteris elegans (PH) & $>50 \%(36,38)$ & $13 \%$ \\
\hline
\end{tabular}

*newly recorded species; „+” present 
( $\mathrm{p}<0.05$ ) with temperature (Table 3). Before 1995, T. elegans was the most abundant species while in this study $P$. longicirrata dominated with relative abundance of $63 \%$ in the pelagic polychaete community (Table 4).

Heteropods Atlanta peronii and Protatlanta souleyeti were the most abundant in their group but they were not so frequent in the plankton. They were registered only in June and July and from September to November, respectively (Table 2). P. souleyeti was not recorded previously in the Middle Adriatic and its abundance was in positive correlation with the temperature $(\mathrm{p}<0.01$, Table 3$)$. $A$. peronii had high relative abundance in the heteropod community of the Middle Adriatic in earlier study as well as in this study (Table 4). In general, heteropods are not numerous, with sporadic occurrence in the Adriatic Sea $(11,33)$.

Among chaetognaths, Sagitta enflata and S. minima were the dominant species (Table 2). Higher abundance of $S$. enflata was found in autumn while $S$. minima peaked in warmer part of the year (Fig. 4). Abundances of $S$. enflata and $S$. minima were in significant positive correlation $(\mathrm{p}<0.001$ and $\mathrm{p}<0.05$, respectively) with temperature (Table 3).

\section{DISCUSSION}

Significant changes in the zooplankton community in the South Adriatic were recorded in 1990s, and were related to drastic changes in the thermohaline circulation of the Eastern Mediterranean (11). Similarly, in 1995/1996 notable changes in the species composition and abundances of the non-crustacean zooplankton communities in the Middle Adriatic were observed, particularly within Calycophorae, Heteropoda, Pteropoda and Polychaeta. Three newly recorded species in the Adriatic Sea, a calycophoran Muggiaea atlantica (25), pteropod Desmopterus papilio, and heteropod Protatlanta souleyeti (26) were found in the open Middle Adriatic in 1995. The pelagic polychaete Pelagobia longicirrata, registered for the first time in the North Adriatic in 1967 (27), has been found after years of absence in the South Adriatic in 1993 (26), and also during this investigation in the Middle Adriatic in 1995. All these species are common members of Atlantic Ocean fauna and have been recorded in the Western Mediterranean over past decades $(28,29,30,31,32)$. The spreading of these species from the south towards the Middle Adriatic occurred in 1995 and coincided with the intrusion of Atlantic water (MAW) into the Adriatic Sea.

Changes of oceanographic properties of the Middle Adriatic from 1991 to 1998 are evident in higher-thanusual nutrient levels, coupled with lower-than-usual temperature, salinity and dissolved oxygen (9). These changes have been attributed to the inflow of the nutrient rich MAW into the Adriatic, caused by the anticyclonic circulation in the North Ionian Gyre. While generally lower temperatures enabled the survival of cold-temperate species such as $M$. atlantica and $P$. longicirrata, two warmtemperate species, $D$. papilio and $P$. souleyeti, were also recorded. However, the latter two species were registered in the warmer part of the year (September, 1995) which probably enabled their survival in relatively colder conditions. Similarly, annual distributions of abundance of $P$. longicirrata and $P$. souleyeti were in strong negative and positive correlation, respectively, with temperature. Apart from species composition, abundances of previously dominant species of calycophorans, pteropods, and polychaetes have also changed dramatically. As noted in the South Adriatic from 1993 to $1996(26,33)$, the progressive dominance of Muggiaea atlantica over the formerly dominant congener $M$. kochii was registered, the pteropod Creseis virgula supplanted C. acicula and the previously very rare Pelagobia longicirrata became dominant pelagic polychaete in the Middle Adriatic in 1995/1996. The analysis of long-term zooplankton data series from the Stončica station (1960-1992) indicated the onset of changes in the abundance of some gelatinous zooplankton from 1980s at station Stončica (19). In addition, from mid ' $80 s$, to mid ' $90 s$, changes were observed in the structure and dynamics of the Northern Adriatic copepod community (34) as well as in the microzooplankton community of the South Adriatic (35). According to the longterm zooplankton data (1993-2011) from the South Adriatic, $M$. atlantica, $P$. longicirrata and $P$. souleyeti became established in the Adriatic zooplankton community while the presence of $D$. papilio depended of the type of current that prevailed in the Adriatic (11).

All these faunal changes can be associated with the change of North Ionian Gyre circulation and, consequently with inflow of Atlantic Water (MAW) into the Adriatic which was uniquely strengthened by the Eastern Mediterranean Transient (EMT) in the early 1990s. The magnitude of influence of this phenomenon on the Mediterranean ecosystem is still not completely known which makes presented data essential in the evaluation of biological changes in the Adriatic Sea. Additionally, these findings will allow us to track future changes in the Adriatic pelagic community in the light of the $\mathrm{BiOS}$ theory and circulation changes in the NIG on decadal time scale.

\section{REFERENCES}

1. OVCHINNIKOV I M, ZATS V I, KRIVOSHEYA V G, UDODOV A I 1985 A forming of deep eastern Mediterranean water in the Adriatic Sea. Okeanologia 25: 911-917 (in Russian)

2. BORZELLI G L E, GAČIĆ M, CARDIN V, CIVITARESE G 2009 Eastern Mediterranean Transient and reversal of the Ionian Sea circulation, Geophys Res Lett 36: L15108 http://dx.doi.org/10.1029/2009GL039261

3. GAČIĆ M, BORZELLI G L E, CIVITARESE G, CARDIN V, YARI S 2010 Can internal processes sustain reversals of the ocean upper circulation? The Ionian Sea example. Geophys Res Letters 37: L09608 
4. GAČIĆ M, SCHROEDER K, CIVITARESE G, COSOLI S, VETRANO A, BORZELLI G L E 2013 Salinity in the Sicily Channel corroborates the role of the Adriatic-Ionian Bimodal Oscillating System (BiOS) in shaping the decadal variability of the Mediterranean overturning circulation. Ocean Sci 9: 83-90. http://dx.doi.org/10.5194/os-9-83-2013

5. CIVITARESE G, GAČIĆ M, LIPIZER M, BORZELLI G L E 2010 On the impact of the bimodal oscillating system (BIOS) on the biogeochemistry and biology of the Adriatic and Ionian Seas (Eastern Mediterranean). Biogeosciences 7: 3987-3997 http://dx.doi.org/10.5194/bg-7-3987-2010

6. ROETHER W, KLEIN B, MANCA B B, THEOCHARIS A, KIOROGLOU S 2007 Transient Eastern Mediterranean deep waters in response to the massive dense-water output of the Aegean Sea in the 1990s. Progress Oceanogr 74: 540-571

7. KLEIN B, ROETHER W, MANCA B B, BREGANT D, BEITZEL V, KOVAČEVIĆ V, LUCHETTA A 1999 The large deep water transient in the Eastern Mediterranean. Deep-Sea Res Pt. I, 46: 371-30 414

8. SAYIN E, BEȘIKTEPE T 2010 Temporal evolution of the water mass properties during the Eastern Mediterranean transient (EMT) in the Aegean Sea. J Geophys Res 115: C10025

9. VILIBIĆ I, MATIJEVIĆ S, ŠEPIĆ J, KUŠPILIĆ G 2012 Changes in the Adriatic oceanographic properties induced by the Eastern Mediterranean Transient. Biogeosciences 9(6): 2085-2097 http://dx.doi.org/10.5194/bg-9-2085-2012

10. MIHANOVIĆ H, VILIBIĆ I, DUNIĆ N, ŠEPIĆ J 2015 Mapping of decadal middle Adriatic oceanographic variability and its relation to the BiOS regime. J Geophys Res Oceans 120: 5615-5630 http://dx.doi.org/10.1002/2015JC010725

11. BATISTIĆ M, GARIĆ R, MOLINERO J C 2014 Interannual variations in Adriatic Sea zooplankton mirror shifts in circulation regimes in the Ionian Sea Climate Res 61: 231-240

12. BULJAN M, ZORE-ARMANDA M 1966 Hydrographic data on the Adriatic Sea collected in the period from 1952 through 1964. Acta Adriat 12: 1-438

13. BULJAN M, ZORE-ARMANDA M 1979 Hydrographic properties of the Adriatic Sea in the period from 1965-1970. Acta Adriat 20: $1-368$

14. BULJAN M 1969 Relation between some factors affecting productivity and fish catch in the central Adriatic area. Stud Rev Gen Fish Coun Mediterr 41: 25-39

15. REGNER D 1981 The changes in seasonal oscillations of copepods in the central Adriatic. Rapp Comm int Mer Médit 27(7): 177-179

16. REGNER D 1991 Long-term investigations of copepods (zooplankton) in the coastal waters of the easterm Middle Adriatic. Acta Adriat 32(2): 631-740

17. BARANOVIĆ A, ŠOLIĆ M, KRSTULOVIĆ N 1993 Temporal fluctuations of zooplankton and bacteria in the middle Adriatic Sea. Mar Ecol Prog Ser 92: 65-75

http://dx.doi.org/10.3354/meps092065

18. ŠOLIĆ M, KRSTULOVIĆ N, MARASOVIĆ I, BARANOVIĆ A, PUCHER-PETKOVIĆ T, VUČETIĆ T 1997 Analysis of time series of planktonic communities in the Adriatic Sea: distinguishing between natural and man-induced changes. Oceanologica Acta 20 (1): 131-143

19. BERLINE L, SIOKOU-FRANGOU I, MARASOVIĆ I, VIDJAK O, FERNÁNDEZ DE PUELLES M-L, MAZZOCCHI M G, ASSIMAKOPOULOU G, ZERVOUDAKI S, FONDA UMANI S, CONVERSI A, GARCIA-COMAS C, IBANEZ F, GASPARINI S, STEMMANN L, GORSKY G 2012 Intercomparison of six
Mediterranean zooplankton time series. Prog Oceanogr 97-100: 76-91 http://dx.doi.org/10.1016/j.pocean.2011.11.011

20. TISCHLER W. 1948 Biocenotische Untersuchungen an Wallhecken.Zool. Jb 77: 283-400

21. BODENHEIMER F. 1955 Precis d'ecologie animale, Paris, p 315

22. BALOGH J. 1958 Lebensgemeinschaften der Landtiere, Berlin, $\mathrm{p}$ 560

23. SOUTHWOOD T R E 1975 Habitat, the templet for ecological strategies. J Anim Ecol 46: 337-365.

24. NAIDENOW W. 1985 Die Auswirkung der Wasserbauten auf das Zooplancton im österreichischen Donauabscchnitt. - In: Naidenow W (ed) Die Auswirkung der Wasserbaulichen Massnahmen und der Belastung auf das Plankton und das Bentos der Donau. Verlag der bulgarischen Akademie der Wissenschaften, Sofia, 72-102

25. GAMULIN T, KRŠINIĆ F 2000 Calychophores (Siphonophora, Calycophorae) of the Adriatic and Mediterranean Seas. Nat Croat 9: $1-198$

26. BATISTIĆ M, KRŠINIĆ F, JASPRICA N, CARIĆ M, VILIČIĆ D, LUČIĆ D 2004 Gelatinous invertebrate zooplankton of the South Adriatic: species composition and vertical distribution. J Plankton Res 24: 459-474 http://dx.doi.org/10.1093/plankt/fbh043

27. POŽAR A 1972 Polychaeta obraštajnih životnih zajednica na različitim podlogama. Rad JAZU 364: 39-46 (in Croatian)

28. FURNESTIN M L 1960 Zooplankton du Golfe du Lion et de côte orientale de Corse. Rev Trav Inst Péches Marit 24: 153-252

29. DI GERONIMO I 1970 Heteropoda e Pteropoda Thecosomata in sedimenti abbissali recenti dello Jonio. Thalassia Salent 4: 41-115

30. RAMPAL J 1975 Les Thécosomes (Mollusques pélagiques). Systématique et évolution - Écologie et biogéographie méditerranéennes. $\mathrm{PhD}$ dissertation, l'Université de Provence, Aix-Marseille, p 485 (in French)

31. PLEIJEL F, DALES R P 1991 Polychaetes: British Phyllodocoideans, Typhloscolecoideans and Tomopteroideans. In: Kermack DM, Barnes RSK (eds) Synopses of the British Fauna (New Series), 45. Universal Book Services, Oegstgeest, p 202

32. PINCA S, DALLOT S 1995 Meso- and macrozooplankton composition patterns related to hydrodynamic structures in the Ligurian Sea (Trophos-2 experiment, April - June 1986). Mar Ecol Prog Ser 126: 49-65 http://dx.doi.org/10.3354/meps126049

33. BATISTIĆ M, JASPRICA N, CARIĆ M, LUČIĆ D 2007 Annual cycle of the gelatinous invertebrate zooplankton of the eastern South Adriatic coast (NE Mediterranean). J Plankton Res 29: 671-686 http://dx.doi.org/10.1093/plankt/fbm048

34. KAMBURSKA L, FONDA-UMANI S 2006 Long-term copepod dynamics in the Gulf of Trieste (Northern Adriatic Sea): recent changes and trends. Clim Res 31: 195-203 http://dx.doi.org/10.3354/cr031195

35. KRŠINIĆ F 2010 Tintinnids (Tintinnida, Choreotrichia, Ciliata) in the Adriatic Sea, Mediterranean. Part I.Taxonomy. Institute for Fisheries and Oceanography, Split, p 186

36. GAMULIN T 1979 Zooplankton istočne obale Jadranskog mora. Acta biol 8:177-270 (in Croatian)

37. LUČIĆ D, MIKUŠ J 1995 Mrežni zooplankton. In: Zvonarić, T (ed.) Kontrola kvalitete obalnog mora. Projekt Vir-Konavle 1994. IOR, pp 67-80.

38. ZEI, M 1956 Pelagic polychaetes of the Adriatic. Thalassia Jugosl 1: $33-68$ 